\title{
CHROMOSOME BANDING STUDIES IN 106 CASES OF CHRONIC MYELOGENOUS LEUKEMIA ${ }^{1}$
}

\author{
Takafumi Tomryasu, Motomichi Sasaki, Koji Kondo, \\ and Michiko OKADA ${ }^{2}$ \\ Chromosome Research Unit, Faculty of Science, Hokkaido \\ University, Sapporo 060, Japan
}

\begin{abstract}
Summary Chromosome banding studies performed on 106 cases of CML in Sapporo revealed that $101(95.3 \%)$ were $\mathrm{Ph}^{1}$-positive, and $5(4.7 \%$ ) $\mathrm{Ph}^{1}$-negative, the latter including a case of juvenile type CML. Of the $101 \mathrm{Ph}^{1}$-positive patients, 98 showed the standard type $\mathrm{Ph}^{1}$ translocation, $\mathrm{t}(9 ; 22)(\mathrm{q} 34 ; \mathrm{q} 11)$, while the remaining 3 had a complex $\mathrm{Ph}^{1}$ translocation as represented by $\mathrm{t}(4 ; 9 ; 22), \mathrm{t}(9 ; 14 ; 22)$, or $\mathrm{t}(9 ; 10 ; 15 ; 19 ; 22)$. There were 28 patients who showed other chromosome changes in addition to the $\mathrm{Ph}^{1}$ translocation. Trisomy 8 , duplication of $\mathrm{Ph}^{1}$, isochromosome $17 \mathrm{q}$, and trisomy 19 were most frequently involved in the additional changes, and 2 or more of them often participated in the major routes of karyotypic evolution. Other additional changes observed were 6 translocations, 4 partial deletions, 2 partial trisomies for $1 \mathrm{q}$, trisomies $6,7,12,15$, and 21 , a monosomy 5, a partial duplication of no. 9, a missing $Y$, and so on.

The present cytogenetic findings were evaluated with respect to some of the clinical and therapeutic parameters.
\end{abstract}

\section{INTRODUCTION}

Since the discovery by Rowley (1973) of a new consistent translocation, $t(9 q+$; $22 \mathrm{q}-$ ), in 9 cases of Philadelphia chromosome $\left(\mathrm{Ph}^{1}\right)$-positive chronic myelogenous leukemia (CML), cytogenetic information is now available on banded karyotypes of more than 1,000 cases of CML reported from a number of laboratories in various countries. Although the overall frequencies of both the standard and variant $\mathrm{Ph}^{1}$ translocations and other types of chromosome abnormalities in CML have been estimated from time to time (Lawler, 1977; Sonta and Sandberg, 1977;

Received February 18, 1982

${ }^{1}$ Supported by a Grant-in-Aid for Cancer Research from the Ministry of Education, Science, and Culture, Japan.

${ }^{2}$ Present address: Department of Anatomy, Tokyo Women's Medical College. Kawadacho, Shinjuku-ku, Tokyo 162, Japan.

Address requests for reprints to: Prof. Motomichi Sasaki, Chromosome Research Unit, Faculty of Science, Hokkaido University, Sapporo 060, Japan. 
FIWCL, 1978; Rowley, 1980; Sandberg, 1980; Mitelman and Levan, 1981), the number of cases dealt with in most of the reported series seems to be still insufficient to allow reasonable comparison of data among different geographic areas or ethnic groups. In fact, we are aware of only 5 original reports in which more than 100 cases of CML were investigated by banding methods (Seabright and Pearson, 1978; Pasquali et al., 1979; Fleischman et al., 1981; Potter et al., 1981; Oshimura et al., 1982).

In this report, we present chromosomal findings in 106 cases of CML referred to us since 1973 to 1980 .

\section{MATERIALS AND METHODS}

The 106 cases of CML referred to us from several hospitals in Sapporo consisted of 1 juvenile and 105 adult type cases, including 2 previously reported ones (Hayata and Sasaki, 1976; Tomiyasu et al., 1980). Sixty-six cases were examined in the chronic phase (CP) only, 19 cases in the blastic phase (BP) only, and 20 cases in both $\mathrm{CP}$ and $\mathrm{BP}$. Chromosome preparations were made by our routine methods on bone marrow and/or peripheral blood cells with or without short term culture. Phytohemaggultinin (PHA)-added blood cultures were made in some instances, For chromosome banding, the QFQ-staining was employed in all cases, while in some cases the GTG-, CBG-, and/or RFA-staining were also used. An abnormal cell line was defined as two or more cells with identical extra chromosomes and/or structural rearrangements, or three or more cells with identical missing chromosomes. Chromosome aberrations and karyotypes were described in accordance with ISCN (1978).

\section{RESULTS}

Of the 106 patients, $101(95.3 \%)$ were found to be $\mathrm{Ph}^{1}$-positive, while the remaining 5 cases including a case of juvenile type were $\mathrm{Ph}^{1}$-negetive. The $\mathrm{Ph}^{1}$ positive cases consisted of 63 males and 38 females. Their ages at diagnosis ranged from 8 to 72 years with the median of 40.5 years, and their survivals after diagnosis 2 to 173 months with the median of 23 months, including the updated data on 24 patients who are still alive.

Of the $101 \mathrm{Ph}^{1}$-positive cases 70 were found to possess the standard $\mathrm{Ph}^{1}$ translocation, $\mathrm{t}(9 ; 22)(\mathrm{q} 34 ; \mathrm{q} 11)$ [hereafter abbreviated as $\mathrm{tPh}^{1}$ ], as a sole abnormality, though one of them had a constitutional reciprocal translocation, $t(6 ; 13)(\mathrm{q} 15 ; \mathrm{q} 34)$, in both $\mathrm{Ph}^{1}$-positive leukemic cells and $\mathrm{Ph}^{1}$-negative $\mathrm{PHA}$-stimulated lymphocytes. Of the 70 cases with $\mathrm{tPh}^{1}, 56(80 \%)$ were examined in $\mathrm{CP}$ only, $10(14 \%)$ in $\mathrm{BP}$ only, and $4(6 \%)$ in both $\mathrm{CP}$ and BP. Supplemental data on the age, sex, survival, status of therapy, and number of cells analyzed for each group of the patients are summarized in Table 1. 


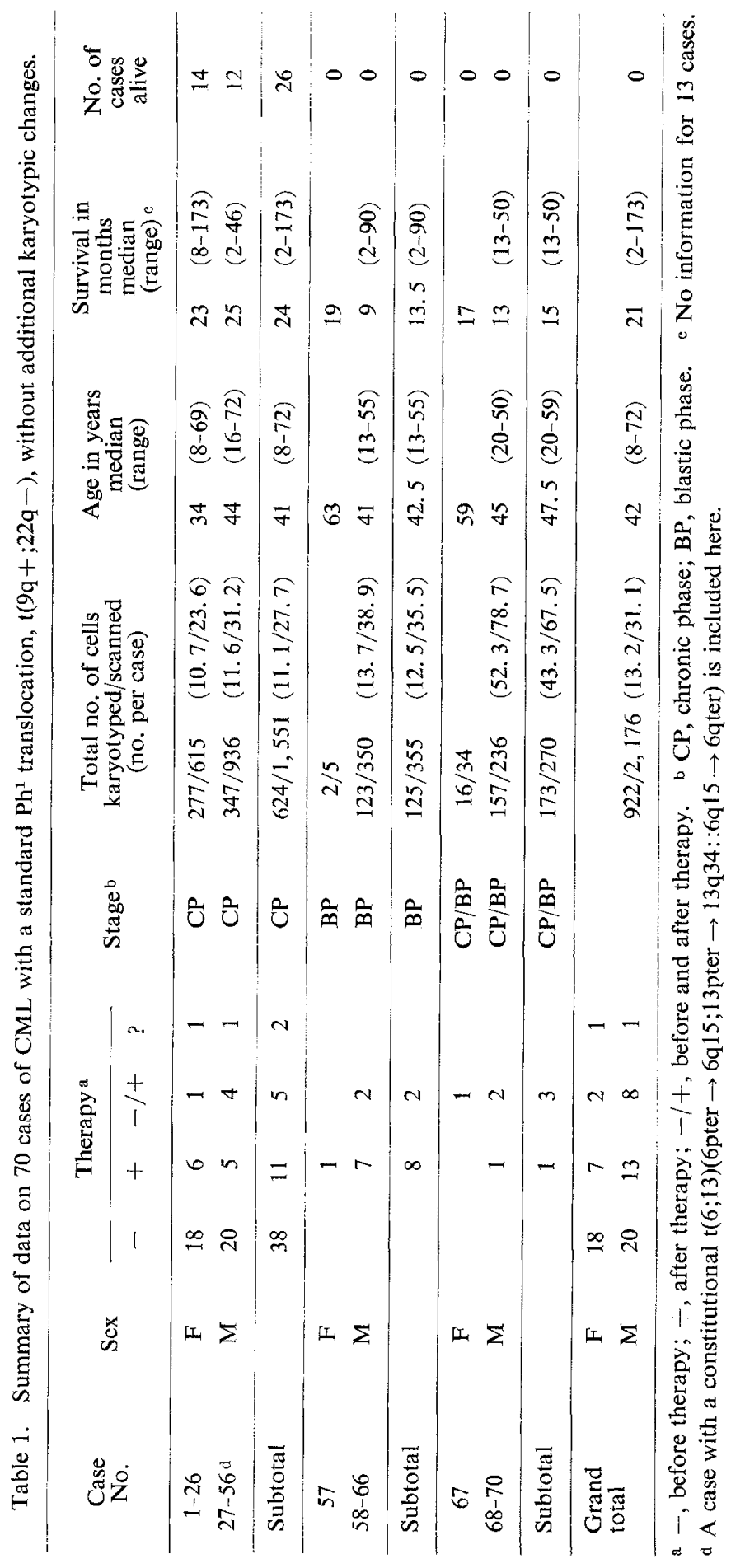


There were 3 cases with a complex $\mathrm{Ph}^{1}$ translocation as represented by $\mathrm{t}(4 ; 9 ; 22)$, $\mathrm{t}(9 ; 14 ; 22)$, and $\mathrm{t}(9 ; 10 ; 15 ; 19 ; 22)$, respectively (Table 2, Fig. 1). These cases were examined in CP only, and had no additional chromosome abnormalities besides the $\mathrm{Ph}^{1}$ translocation. The last case (Case 73) has been reported by Hayata and Sasaki (1976).

The remaining 28 cases had various types of chromosomal changes in addition to $\mathrm{Ph}^{1}$ (Table 3 ). The additional abnormalities were found in 5 cases examined

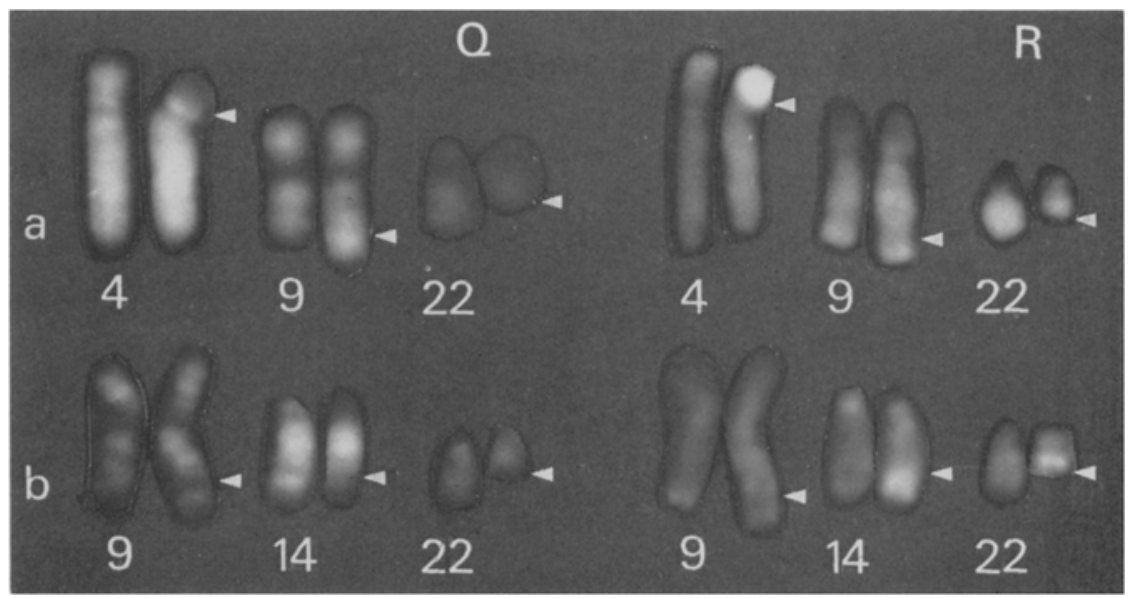

Fig. 1. Partial Q- and R-band karyotypes of Cases 71 (a) and 72 (b), shwong complex Ph $^{1}$ translocations involving chromosomes 4, 9, and 22, and chromosomes 9, 14, 22, respectively. Arrow heads indicate the break points.

Table 2. Cytogenetic and some clinical data in 3 cases of CML with a complex $\mathrm{Ph}^{1}$ translocation.

\begin{tabular}{|c|c|c|c|c|c|c|c|}
\hline $\begin{array}{l}\text { Case } \\
\text { No. }\end{array}$ & $\begin{array}{l}\text { Patient } \\
\text { code }\end{array}$ & $\begin{array}{l}\text { Age } \\
(\mathrm{y})\end{array}$ & Sex & $\begin{array}{l}\text { Survival } \\
(\mathrm{m})\end{array}$ & Therapy a & Specimen $\mathrm{b}$ & $\begin{array}{l}\text { Karyotype and no. } \\
\text { of cells analyzed (scanned) }\end{array}$ \\
\hline \multirow[t]{2}{*}{71} & $531, \mathrm{KK}$ & 61 & $\mathrm{~F}$ & $43+$ & - & BM-d,c & $\begin{array}{l}46, \mathrm{XX}, \mathrm{t}(4 ; 9 ; 22)(4 \mathrm{qter} \rightarrow 4 \mathrm{p} 14:: 22 \mathrm{q} 11 \\
\rightarrow 22 \mathrm{qter} ; 9 \mathrm{pter} \rightarrow 9 \mathrm{q} 34:: 4 \mathrm{p} 14 \rightarrow 4 \mathrm{pter} ; \\
22 \text { pter } \rightarrow 22 \mathrm{q} 11)=12(63)\end{array}$ \\
\hline & & & & & + & $B M-d$ & The same karyotype as above $=17(32)$ \\
\hline 72 & $753, \mathrm{AT}$ & 22 & M & $11+$ & - & BM-d & $\begin{array}{l}46, \mathrm{XY}, \mathrm{t}(9 ; 14 ; 22)(9 \mathrm{pter} \rightarrow 9 \mathrm{q} 34:: 14 \mathrm{q} 24 \\
\rightarrow 14 \mathrm{qter} ; 14 \mathrm{pter} \rightarrow 14 \mathrm{q} 24:: 22 \mathrm{q} 11 \rightarrow \\
22 \mathrm{qter} ; 22 \text { pter } \rightarrow 22 \mathrm{q} 11)=13(35)\end{array}$ \\
\hline $73^{d}$ & $396, \mathrm{OK}$ & 23 & $\mathrm{M}$ & ? & - & BM-d,c & $\begin{array}{l}46, \mathrm{XY}, \mathrm{t}(9 ; 10 ; 15 ; 19 ; 22)(9 \mathrm{pter} \rightarrow 9 \mathrm{q} 34:: \\
10 \mathrm{q} 22 \rightarrow 10 \mathrm{qter} ; 10 \mathrm{q} 22 \rightarrow 10 \mathrm{pter}:: 19 \mathrm{q} 13 \\
\rightarrow 19 \mathrm{qter} ; 15 \mathrm{pter} \rightarrow 15 \mathrm{q} 21:: 22 \mathrm{q} 12 \rightarrow \\
22 \mathrm{qter} ; 19 \text { pter } \rightarrow 19 \mathrm{q} 13:: 15 \mathrm{q} 21 \rightarrow \\
15 \mathrm{qter} ; 22 \text { pter } \rightarrow 22 \mathrm{q} 12)=50(50)\end{array}$ \\
\hline
\end{tabular}

a - , before therapy; +, after therapy. b BM, bone marrow; d, direct preparation; c, cultured. c No. of cells karyotyped is indicated after the equal sign, and no. of cells scanned in the parentheses. d Previously reported case (Hayata and Sasaki, 1976). All cases were examined in the chronic phase only. The plus sign in survival indicates that the patient is still alive. 
in $\mathrm{CP}$ only, 8 cases in BP only, and 15 cases in both $\mathrm{CP}$ and BP. Among the latter 15 cases, 13 had additional abnormalities in $\mathrm{BP}$ only, whereas the remaining 2 exhibited the same types of abnormalities in both CP and BP. All of the 23 cases that were studied in BP had received therapy. Out of the 20 cases that were studied in CP, 3 cases were examined after therapy, while 4 cases were studied before and after therapy, leaving 13 cases which had never been treated. The additional abnormalities in CP were found in 6 out of the former 7 cases, and in 1 of the latter 13 cases. It should be mentioned, however, that in 2 of the 4 cases studied before and after therapy in $\mathrm{CP}$, the additional changes were detected even before therapy.

Allowing repetition in scoring the cases, a trisomy $8[+8]$ was found in 14 cases, an extra $\mathrm{Ph}^{1}\left[+\mathrm{Ph}^{1}\right]$ in 13 cases, an isochromosome for the long arm of chromosome $17[\mathrm{i}(17 \mathrm{q})]$ in 6 cases, a trisomy $19[+19]$ in 6 cases, translocations in 6 cases, partial deletions in 4 cases, and partial trisomies for the long arm of chromosome 1 , a trisomy $7[+7]$ and a trisomy $21[+21]$, each in 2 cases. Other changes that were encountered only once were monosomy 5 , trisomies $6,12,15$, and 17 , a partial duplication for the long arm of chromosome 9, an additional segment on $21 \mathrm{q}[21 \mathrm{q}+]$, a missing $\mathrm{Y}[-\mathrm{Y}]$, a marker chromosome of unknown origin [+mar], and multiple changes including a trisomy 1 and a possible isochromosome for the long arm of chromosome 2 (Table 3).

Among the 14 cases with $\mathrm{tPh}^{1},+8$ (Cases 74-87), Cases $74-75$ were found to be accompanied with $\mathrm{i}(17 \mathrm{q})$, Cases $76-78$ with $\mathrm{i}(17 \mathrm{q}),+\mathrm{Ph}^{1}$, Case 79 with $\mathrm{i}(17 \mathrm{q})$, $+19,+\mathrm{Ph}^{1}$, Cases $80-82$ with $+\mathrm{Ph}^{1}$, Case 83 with $+6,+19,+21,+\mathrm{Ph}^{1}$, Case 84 with $+7,+12,+15,21 q+$, Case 85 with $+17,+19$, dup $(9 q+)$, and Case 86 with $-5,+$ mar. While in the remaining one (Case 87 ) the +8 was the only anomaly additional to the $\mathrm{Ph}^{1}$. Thus $+\mathrm{Ph}^{1}$ was most frequent companion with +8 which occurred in 8 cases, while $\mathrm{i}(17 \mathrm{q})$ and +19 coexisted with +8 in 6 and 3 cases, respectively. Other abnormalities, $-5,+6,+7,+12,+15,+21, \operatorname{dup}(9 q+), 21 q+$, and + mar were encountered only once in association with +8 . The dup $(9 q+)$ found in Case 85 was a derivative of the $9 q+$ marker, the regular partner of the $\mathrm{Ph}^{1}$, in that an interstitial segment, $9 \mathrm{q} 13 \rightarrow 9 \mathrm{q} 22$, was tandemly duplicated, which was tentatively designated as $\mathrm{tPh}^{1}, \operatorname{dup}(9 \mathrm{q}+)(\mathrm{q} 13 \rightarrow \mathrm{q} 22)$. Case 79 was unique in that all of the above mentioned regular companions, i.e., $+8, \mathrm{i}(17 \mathrm{q}),+19$, and $+\mathrm{Ph}^{1}$ were observed in cultured peripheral blood cells examined on 3 occasions in BP. The major direction in this case of the karyotypic evolution appeared to be $\mathrm{tPh}^{1} \rightarrow$ $\mathrm{tPh}^{1}, \mathrm{i}(17 \mathrm{q}) \rightarrow \mathrm{tPh}^{1}, \mathrm{i}(17 \mathrm{q}),+8 \rightarrow \mathrm{tPh}^{1}, \mathrm{i}(17 \mathrm{q}),+8,+19$, although a minor clone with $\mathrm{tPh}^{1},+\mathrm{Ph}^{1}$ which was present in the 2 nd $\mathrm{BP}$ sample disappeared thereafter $\mathrm{A}$ similar short-lived clone with a combination of $\mathrm{tPh}^{1}, \mathrm{i}(17 \mathrm{q}),+\mathrm{Ph}^{1}$ was noted in Case 78. In $\mathrm{CP}$ of this case, $\mathrm{tPh}^{1}$ was the sole abnormality, whereas 3 other cell lines with either $\mathrm{tPh}^{1}, \mathrm{i}(17 \mathrm{q})$; $\mathrm{tPh}^{1}, \mathrm{i}(17 \mathrm{q}),+8$; or $\mathrm{tPh}^{1}, \mathrm{i}(17 \mathrm{q}),+\mathrm{Ph}^{1}$, were observed on 4 subsequent examinations in BP. As shown in Table 4, the cells with $\mathrm{CPh}^{1}$, $\mathrm{i}(17 \mathrm{q}),+\mathrm{Ph}^{1}$, which were detected in the 2 nd $\mathrm{BP}$ sample, suddenly disappeared 


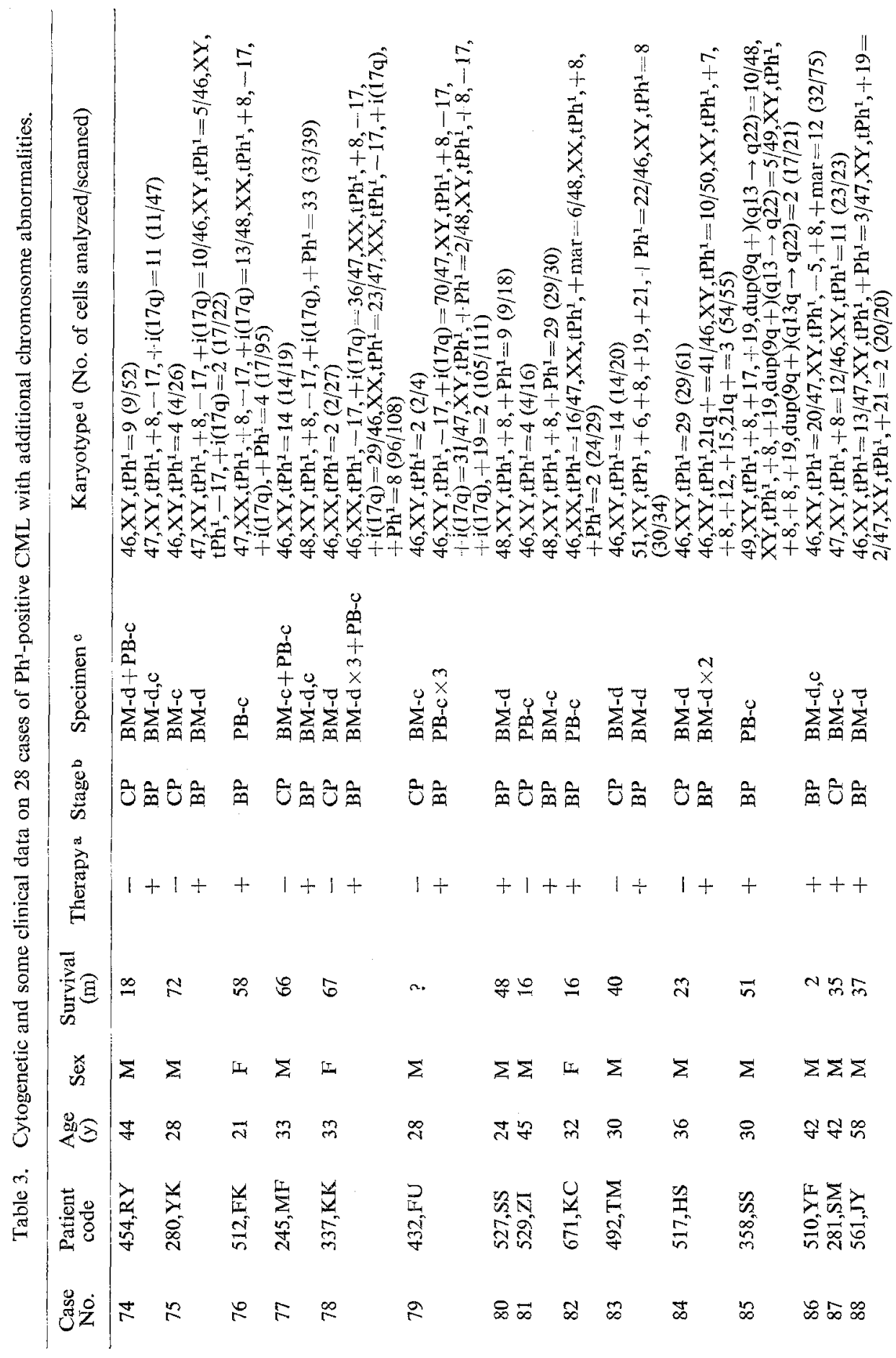



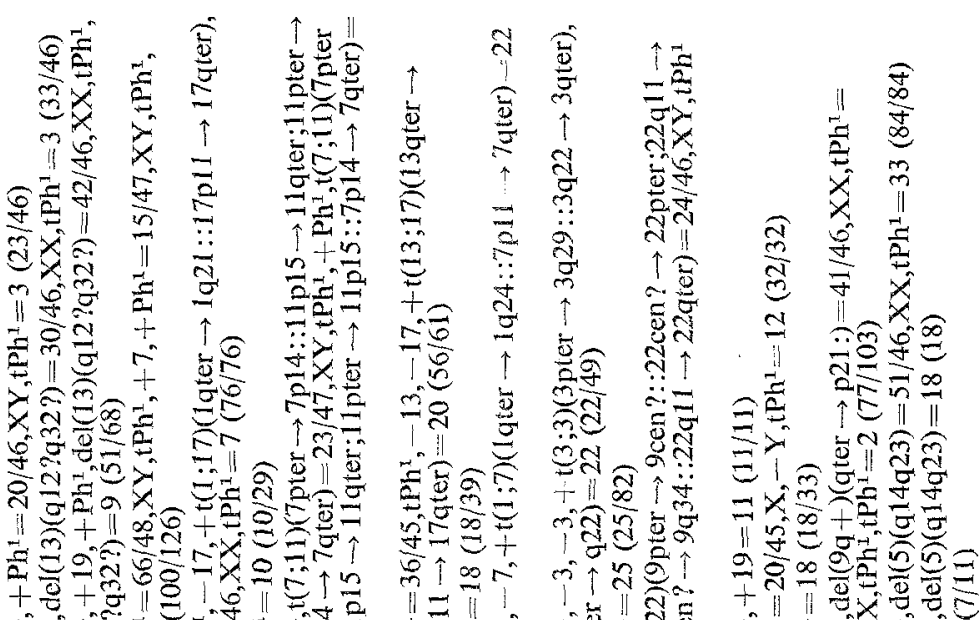

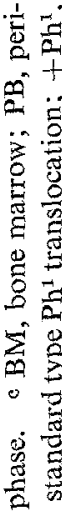
驮要早

तथत्य

$+=+$

氙

$+\frac{0}{2} \|$ l.

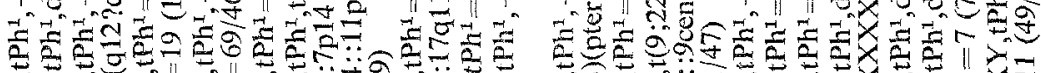

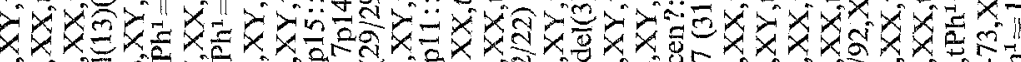

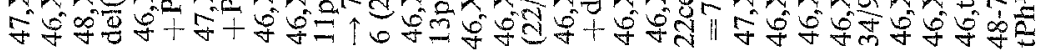

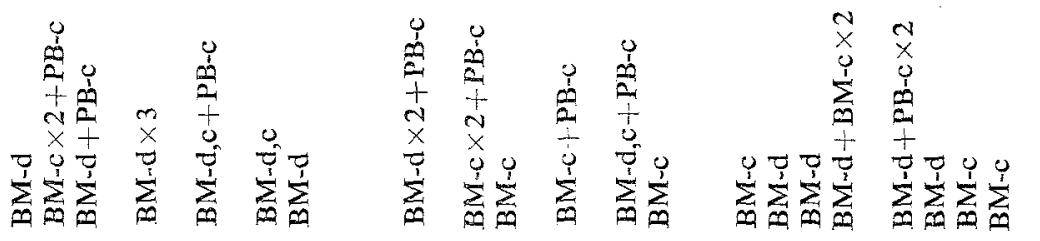

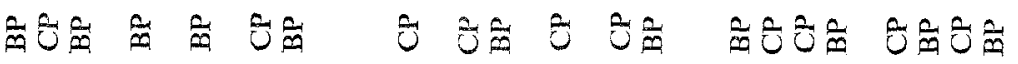
$+\frac{+}{1}+++1+\frac{+}{1}++1++1+\frac{+}{1}+1+$

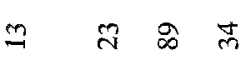

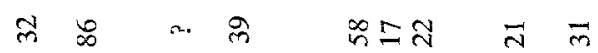

I $\Sigma \Sigma \sum$

$\sum \Sigma \sum \Sigma$

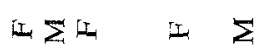

n ते m

अ $\overline{4}$ क

mi요 त 항

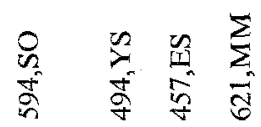

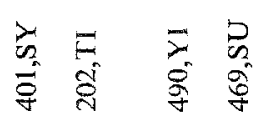

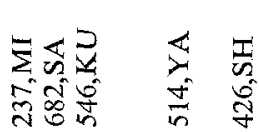

ஓ ๙

2 2 \&

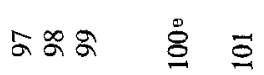


within a week or so. The major route of karyotypic evolution in this case was thought to be $\mathrm{tPh}^{1} \rightarrow \mathrm{t} \mathrm{Ph}^{1}, \mathrm{i}(17 \mathrm{q}) \rightarrow \mathrm{tPh}^{1}, \mathrm{i}(17 \mathrm{q}),+8$, which took over another route, possibly blanched off from $\mathrm{tPh}^{1}, \mathrm{i}(17 \mathrm{q})$ to $\mathrm{tPh}^{1}, \mathrm{i}(17 \mathrm{q}),+\mathrm{Ph}^{1}$.

Table 4. Karyotype analyses in Case 78 (337,KK).

\begin{tabular}{|c|c|c|c|c|c|c|}
\hline \multirow[b]{2}{*}{ Date } & \multirow[b]{2}{*}{ Specimen ${ }^{a}$} & \multirow[b]{2}{*}{$\begin{array}{l}\text { Clinical } \\
\text { phase }^{b}\end{array}$} & \multicolumn{4}{|c|}{ No. of cells with } \\
\hline & & & $\mathrm{tPh}^{1 \mathrm{c}}$ & $\begin{array}{l}\mathrm{tPh}^{1} \\
\mathrm{i}(17 \mathrm{q})\end{array}$ & $\begin{array}{c}\mathrm{tPh}^{1} \\
\mathrm{i}(17 \mathrm{q}) \\
+8\end{array}$ & $\begin{array}{l}\mathrm{tPh}^{1} \\
\mathrm{i}(17 \mathrm{q}) \\
-\mathrm{Ph}^{1} d\end{array}$ \\
\hline $10 / 18 / 74$ & $B M-d$ & $\mathrm{CP}$ & 27 & & & \\
\hline $11 / 24 / 78$ & BM-d & $\mathrm{BP}$ & 18 & 10 & 2 & \\
\hline $12 / 14 / 78$ & $B M-d$ & $\mathrm{BP}$ & & 12 & 10 & 8 \\
\hline $12 / 22 / 78$ & $\mathrm{BM}-\mathrm{d}$ & $\mathrm{BP}$ & 5 & 12 & 4 & \\
\hline $2 / 5 / 79$ & $\mathrm{~PB}-\mathrm{C}$ & $\mathrm{BP}$ & & 2 & 13 & \\
\hline
\end{tabular}

a $\mathrm{BM}$, bone marrow; $\mathrm{PB}$, peripheral blood; $\mathrm{d}$, direct preparation; $\mathrm{c}$, cultured. $\mathrm{b} \mathrm{CP}$, chronic phase; $\mathrm{BP}$, blastic phase. $\quad{ }^{\circ} \operatorname{Ph}^{1}, \mathrm{t}(9 ; 22)(\mathrm{q} 34 ; \mathrm{q} 11) . \mathrm{d}+\mathrm{Ph}^{1},+22 \mathrm{q}-$.

In addition to the aforementioned 8 cases comprising $+8,+\mathrm{Ph}^{1}$ (Cases $76-$ 83), there were found 5 cases (Cases 88-92) which showed a $+\mathrm{Ph}^{1}$ and some other anomalies, as represented by $+19,+21 ;+19$, del $(13) ;+7 ; \mathfrak{t}(1 ; 17) ;$ and $\mathfrak{t}(7 ; 11)$, respectively. In Case 88 , despite the existence of 4 cell lines $\left[\mathrm{tPh} ; \mathrm{tPh}^{1},+\mathrm{Ph}^{1}\right.$; $\mathrm{tPh}^{1},+19$; and $\left.\mathrm{tPh}^{1},+21\right]$ in the 1st $\mathrm{BP}$ sample, the final cell population studied in the 2nd BP sample was taken over exclusively by a single cell line with $\mathrm{tPh}^{1},+\mathrm{Ph}^{1}$. Case 89 was analyzed 3 times in CP and twice in BP. The 1st (before therapy) and the 2 nd (after therapy) analyses in CP revealed 2 cell lines with either $\mathrm{tPh}^{1}$ or $\mathrm{tPh}^{1}$,del(13)(q12?q32?). While the latter cell line persisted throughout the subsequent studies, its derivative line showing a $\mathrm{tPh}^{\mathbf{1}},+19,+\mathrm{Ph}^{1}, \mathrm{del}(13)$ constitution suddenly predominated in the 4 th and 5 th samples.

Case 90 was studied 3 times in BP. The 1st study disclosed 2 abnormal karyotypes, $46, \mathrm{Ph}^{1}$ and $48, \mathrm{tPh}^{1},+7,+\mathrm{Ph}^{1}$, in the proportion of $2: 1$. The incidence of the latter cell type decreased to less than $1 \%$ in the 2 nd sample, and all cells analyzed in the 3rd sample showed a new karyotype, $47, \mathrm{Ph}^{1},+\mathrm{Ph}^{1}$.

The 2 translocations, an unbalanced $t(1 ; 17)$ and a reciprocal $t(7 ; 11)$ found in Cases 91 and 92, respectively, appeared to have occurred in preexisted $46, \mathrm{Ph}^{1}$ cell, followed by an additional karyotypic change with $+\mathrm{Ph}^{1}$. Four other translocations found in Cases $93-96$ were $t(13 ; 17) ; t(1 ; 7) ; t(3 ; 3)$, del( 3$)$; and $t(9 ; 22)$ involving four-break rearrangements by which the original $\mathrm{Ph}^{1}$ chromosome was masked (Table 3, Fig. 2). None of the break points involved in the formation of the above 6 translocations were identical, whereas the 2 unbalanced translocations, $t(1 ; 17)$ of Case 91 and $t(1 ; 7)$ of Case 94. (Fig. 3), which produced partially 
trisomic conditions for the long arm of chromosome 1, appeared to share a common segment of duplication from $1 \mathrm{q} 24$ to 1 qter.

Case 97 had a $\mathrm{tPh}^{1},+19$ constitution in all cells examined before therapy in CP. Case 98 also examined only once in untreated CP, contained 2 cell lines with either $\mathrm{tPh}^{1}$ or $\mathrm{tPh}^{1},-\mathrm{Y}$, indicating that the missing $\mathrm{Y}$ was a secondary event.

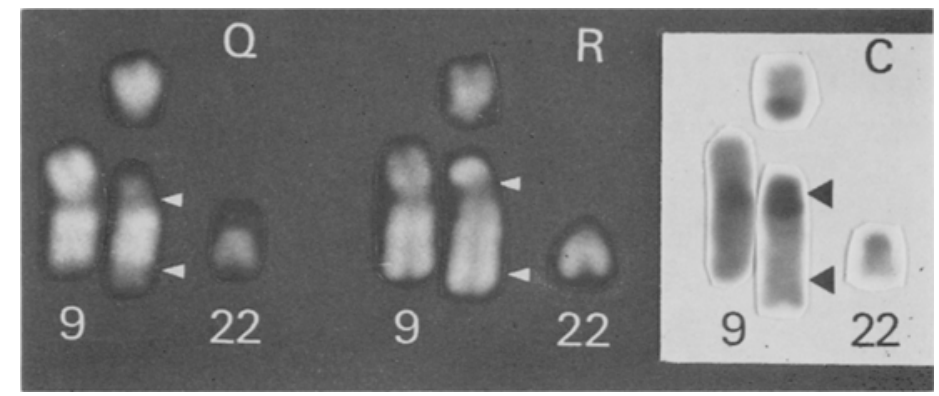

Fig. 2. Partial Q-, R-, and C-band karyotypes of Case 96 , showing a masked $\mathrm{Ph}^{1}$ translocation. Arrow heads indicate the break points.

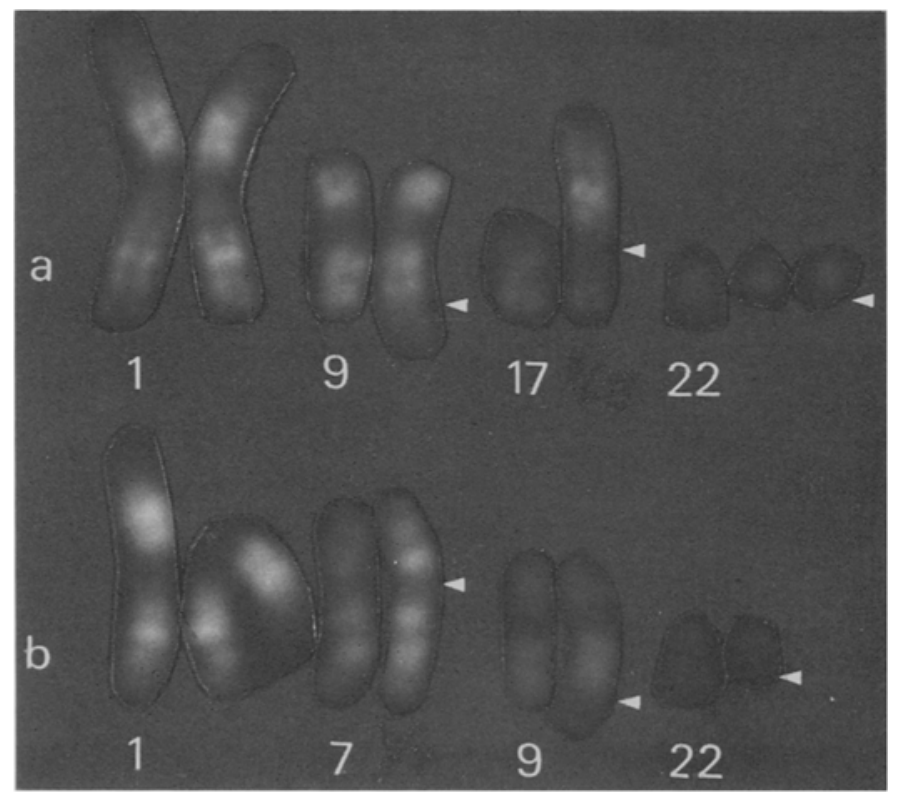

Fig. 3. Partial Q-band karyotypes of Cases 91 (a) and 94 (b), showing partial trisomies for the long arm of chromosome 1. Arrow heads indicate the break points.

Case 99 which showed a $\mathrm{tPh}^{1}$ karyotype in the 1st BP sample taken before therapy acquired a possible terminal deletion in the $\mathrm{tPh}^{1}$-derived $9 \mathrm{q}+$, with a break point at band $9 \mathrm{p} 21$. The karyotype was tentatively designated as $\mathrm{tPh}^{1}$, 


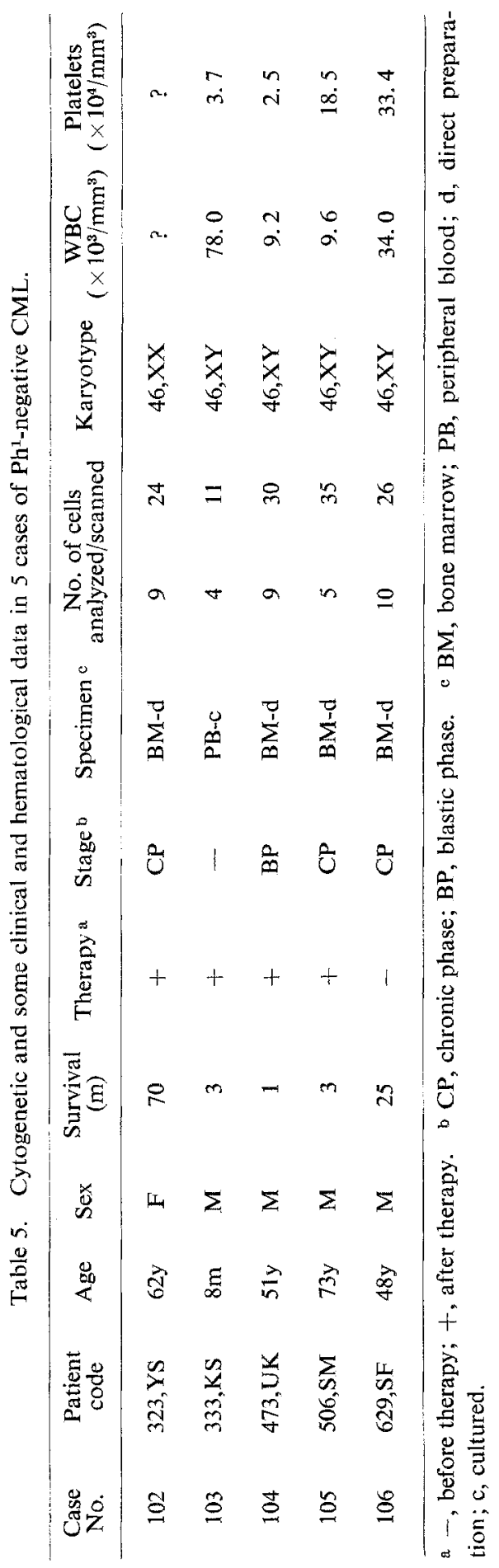


$\operatorname{del}(9 q+)(q$ ter $\rightarrow p 21:)$. This deletion was found in about $80 \%$ of cells in the 2nd direct marrow sample taken after therapy, in coexistence with $20 \%$ of the original $\mathrm{tPh}^{1}$ cells. However, in both the $3 \mathrm{rd}$ and 4 th marrow samples which were studied in culture, the incidence of the del $(9 q+)$ cells decreased to $10 \%$ or less, and the $\mathrm{tPh}^{1}$ cells became predominant. A small fraction of tetraploid cells with $2 \mathrm{Ph}^{1}$ chromosomes was noted in the 4 th sample

Case 100 was a previously reported case (Tomiyasu et al., 1980) which had an interstitial deletion of the long arm of chromosome 5, del(5)(q14q23), in addition to $\mathrm{tPh}^{\mathbf{1}}$.

Case 101 was started with $\mathrm{tPh}^{1}$ in CP. In the 2 nd sample, which was taken after therapy in BP and examined in culture, there were observed very dramatic chromosome changes as represented by widespread chromosome numbers ranging from 48 to 73 together with various numerical and structural variations. Among these multiple changes, an excess number of chromosome 1 and a possible isochromosome for the long arm of chromosome 2 were common features. About onequater of cells in the $2 \mathrm{nd}$ sample had a $46, \mathrm{thh}^{\mathbf{1}}$ karyotype.

All of the $5 \mathrm{Ph}^{1}$-negative cases including a juvenile type case of CML showed exclusively a normal karyotype without any detectable abnormality in banding patterns of individual chromosomes (Table 5).

\section{DISCUSSION}

Our data on the type and frequency of chromosome abnormalities in 106 cases of CML appeared to be somewhat different from those reported by the FIWCL (1978) and some other authors who studied relatively large numbers of CML cases (Lawler et al., 1976; Engel et al., 1977; Seabright and Pearson, 1978; Pasquali et al., 1979; Stoll and Oberling, 1979; Bernstein et al., 1980; Hagemeijer et al., 1980; Kohno and Sandberg, 1980; Sadamori et al., 1980; Fleischman et al., 1981; Potter et al., 1981 ; Oshimura et al., 1982).

The frequency of $\mathrm{Ph}^{1}$-negative $\mathrm{CML}$ cases in our series $(3.8 \%=4 / 105$, excluding a case of juvenile type) seems to be lower than the usual incidence of $10-15 \%$, even though the incidence varies among different laboratories, ranging from $0 \%$ to more than 30\% (Sandberg, 1980). Relatively shorter survivals, lower WBC and platelet counts, and higher ages were noted in some of our $\mathrm{Ph}^{1}$-negative cases, as have been suggested to be general trends of $\mathrm{Ph}^{1}$-negative CMLs (Ezdinli et al., 1970; Canellos et al., 1976). The absence of the $\mathrm{Ph}^{1}$ chromosome in the juvenile type CML is not unusual (Brodeur et al., 1979).

The present incidence of variant $\mathrm{Ph}^{1}$ translocations ( 3 of $101 \mathrm{Ph}^{1}$-positive cases) seemed to be lower than the usual incidence, $8 \%$ (FIWCL, 1978), and all of the 3 variants were of complex type, the simple type being absent in our series. The hematological and clinical findings of these 3 cases did not show much deviations from those of the cases with a standard $\mathrm{Ph}^{1}$ translocation (Sonta and Sandberg, 
1977), except for rather high percentages of myeloblasts and promyelocytes in CP of Case 73. This case was unusual in that 5 different chromosomes were involved in the formation of the complex translocation. Complex $\mathrm{Ph}^{1}$ translocations involving chromosome 4 have been reported in 7 cases (Rowley et al., 1976; Geraedts et al., 1977; Chessells et al., 1979; Pasquali et al., 1979; Fraisse et al., 1980; Kessous et al., 1980; Sudries et al., 1980), but the break point in the affected no. 4 of $\mathrm{t}(4$; $9 ; 22)$ in Case 71 was different from those in the reported cases. The complex $\mathrm{Ph}^{1}$ translocation, $\mathrm{t}(9 ; 14 ; 22)$, found in Case 72 and 3 reported cases (Potter et al., 1975; Borgström, 1981; Shabtai et al., 1980) appeared to have the same break point at $14 \mathrm{q} 24$, whereas the break point in another reported case (Kolitz et al., 1981) of $\mathrm{t}(9 ; 14 ; 22)$ was located at $14 \mathrm{q} 32$.

In the present study, the overall incidence of $\mathrm{Ph}^{1}$-positive cases with additional changes was $27.7 \%(28 / 101) ; 9.5 \%(8 / 84)$ in $\mathrm{CP}$ and $62.2 \%(23 / 37)$ in BP. Limiting the data on 20 cases which were studied in both $\mathrm{CP}$ and BP, the incidence was estimated to be $15 \%(3 / 20)$ in $\mathrm{CP}$, and $65 \%(13 / 20)$ in BP. These values do not seem to be much deviating from those reported from other laboratories, where the incidence varied from less than 10\% (Bernstein et al., 1980) to $20-30 \%$ in CP (Hayata et al., 1975; Lawler et al., 1976; Sonta and Sandberg, 1978; Kohno and Sandberg, 1980), and from 60\% (Pasquali et al., 1979) to more than $85 \%$ in BP (Sonta and Sandberg, 1978; Stoll and Oberling, 1979; Bernstein et al., 1980).

The most frequent additional changes in our cases were $+8, \mathrm{i}(17 \mathrm{q}),+19$, and $+\mathrm{Ph}^{1}$, and two or more of them were often observed in the same cell or cell population, being in agreement with previous studies as reviewed by some authors (Lawler, 1977; Rowley, 1980; Sandberg, 1980; Mitelman and Levan, 1981). These additional changes are assumed to have occurred in preexisted $\mathrm{Ph}^{1}$-positive cells either in $\mathrm{CP}$ or $\mathrm{BP}$, with preferential combinations of $+8,+\mathrm{Ph}^{1}$; $+8,1(17 \mathrm{q})$; or $+8,+19$, attaining further karyotypic evolution toward $+8, \mathrm{i}(17 \mathrm{q}),+\mathrm{Ph}^{1} ;+8, \mathrm{i}(17 \mathrm{q})$, +19 ; or $+8, \mathrm{i}(17 \mathrm{q}),+19,+\mathrm{Ph}^{1}$. In contrast, a single addition to $\mathrm{Ph}^{1}$ of +8 (Case 87 ) or $+\mathrm{Ph}^{1}$ (Case 79) was less frequent or rather short-lived, the latter being taken over by different cell lines having possibly more adaptive or grave-destined combinations, starting with $\mathrm{tPh}^{\mathrm{1}}, \mathrm{i}(17 \mathrm{q})$ and ending with $\mathrm{tPh}^{1}, \mathrm{i}(17 \mathrm{q}),+8,+19$. Another combination in Case 78 with $\mathrm{tPh}^{1}, \mathrm{i}(17 \mathrm{q}),+\mathrm{Ph}^{1}$ was also short-lived, being rapidly taken over by $\mathrm{tPh}^{1}, \mathrm{i}(17 \mathrm{q}),+8$, and hence rarely found; only 3 cases with this combination have been reported to date (Stoll and Oberling, 1979). It is interesting that in Case 88 which had neither +8 nor $\mathrm{i}(17 \mathrm{q})$, a cell line with $\mathrm{tPh}^{1},+\mathrm{Ph}^{1}$ predominated over 3 other cell lines with $\mathrm{tPh}^{1} ; \mathrm{tPh}^{1},+19$; or $\mathrm{tPh}^{1},+21$.

Apart from the aforementioned relatively common additional changes, all of the 6 translocations and 4 partial deletions were of different origin, in terms of the break points involved in the formation of such anomalies. However, the partially trisomic condition of $1 \mathrm{q}$ as resulted from the translocations in Cases 91 and 94 may merit special attention, since similar secondary changes, with a common trisomic segment of $1 \mathrm{q} 25 \rightarrow 1 \mathrm{q} 32$, have been suggested to occur rather frequently in 
various blood disorders (Gahrton et al., 1978; Rowley 1978; Alimena et al., 1980; Miyamoto et al., 1981; Slavutsky et al., 1981). The del(5) in Case 100 may bear a similar implication, as have been discussed elsewhere (Tomiyasu et al., 1980; Mitelman and Levan, 1981).

It has been suggested that the observation of additional chromosome abnormalities at the time of diagnosis in CP may not have significance on the progression of the disease (Sandberg, 1978). Out of our 28 patients who showed additional abnormalities (Table 3), 17 were examined before therapy in CP. Among the latter 17 , only 3 (Cases 89,98 , and 100) showed additional changes at or soon after diagnosis before therapy in $\mathrm{CP}$; their survivals were 13,17 , and 21 months, respectively. In the remaining 14 patients who did not show additional changes before therapy in $\mathrm{CP}$, their survivals ranged from 16 to 86 months, with the mean of 42 months and the median of 34 months. The different survivals between the above two groups were not significant statistically $(0.05<\mathrm{p}<0.1)$. On the other hand, the median survival for all of the 28 patients who developed additional changes was rather longer than that of the 70 patients without further changes; 34.5 vs. 21 months. However, the latter figure can not properly be compared to the contradictory findings of Sonta and Sandberg (1978), and Prigogina et al. (1978); since more than one third of the 70 patients are still alive, with an unusually long chronic phase, much longer median survival is expected for the latter group of our patients.

Alimena et al. (1979) have reported that about $85 \%$ of their $34 \mathrm{Ph}^{1}$-positive

Table 6. Summary of therapeutic and cytogenetic data on $97 \mathrm{Ph}^{1}$-positive CML patients.

\begin{tabular}{|c|c|c|c|c|c|c|c|}
\hline & & & \multicolumn{5}{|c|}{ No. of cases with } \\
\hline \multicolumn{3}{|c|}{$\begin{array}{l}\text { No. of cases in which karyotype } \\
\text { analyses were performed in }\end{array}$} & \multicolumn{3}{|c|}{$\begin{array}{l}\mathrm{Ph}^{1} \text { translocation } \\
\text { only a }\end{array}$} & \multirow{2}{*}{$\begin{array}{c}\begin{array}{c}+8, \mathrm{i}(17 \mathrm{q}),+\mathrm{Ph}^{1} \\
\text { and/or }+19\end{array} \\
1^{*} \quad\left(1^{*}\right)^{\mathrm{b}}\end{array}$} & \multirow{2}{*}{$\begin{array}{l}\begin{array}{c}\text { Other } \\
\text { structural } \\
\text { changes }\end{array} \\
0\end{array}$} \\
\hline CP before therapy only & 40 & & 39 & $(2)^{a}$ & & & \\
\hline $\mathrm{CP}$ after therapy only & 14 & {$[2] \mathrm{c}$} & 12 & & {$[2]^{\mathrm{c}}$} & 2 & 0 \\
\hline BP after therapy only & 14 & {$[5]^{\mathrm{c}}$} & 7 & & {$[2]^{c}$} & $(2)^{b} \quad[3]^{c}$ & $(1)^{b}$ \\
\hline \multirow[t]{4}{*}{$\mathrm{CP} / \mathrm{BP}$ before and after therapy } & 29 & {$[3]^{c}$} & 13 & $(1)^{a}$ & {$[1]^{c}$} & \multicolumn{2}{|c|}{ Changes only after therapy } \\
\hline & & & & & & $7 \quad(1)^{b} \quad[2] \mathfrak{c}$ & $7 \quad(1) b$ \\
\hline & & & & & & \multicolumn{2}{|c|}{ Before and after therapy } \\
\hline & & & & & & 0 & 2 \\
\hline Total & 97 & {$[10]^{\mathrm{c}}$} & 71 & $(3)^{2}$ & {$[5] \mathrm{c}$} & $(4)^{b} \quad[5] \mathrm{c}$ & $(2)^{b}$ \\
\hline
\end{tabular}

a Three cases with a complex $\mathrm{Ph}^{\mathrm{I}}$ translocation were shown in parentheses. b No. of cases with other numerical changes in addition to $+8,(17 \mathrm{q}),+\mathrm{Ph}^{1}$ and/or +19 was shown in parentheses, except 1 case with $-Y$ only which was indicated by an asterisk. ${ }^{c}$ No. of patients who received intensive chemotherapy with 6-mercaptopurine, prednisone, and/or cyclophosphamide before chromosome analyses was shown in brackets, on the basis of 77 patients with whom exact records of therapy were available. $\mathrm{CP}$, chronic phase; $\mathrm{BP}$, blastic phase. 
CML patients had $+8, \mathrm{i}(17 \mathrm{q})$, and/or $+\mathrm{Ph}^{1}$, and that the frequency of each of these relatively common changes was not significantly different between the following two groups of patients: one treated with busulfan only, and the other received intensive chemotherapy with cytarabine, vincristine, daunorubicin, and/or thioguanine. Their results also indicated that other structural abnormalities of a clonal nature, especially those involving chromosome 1 , were more frequent in the latter group of patients. Two of our patients (Cases 91 and 94) who showed structural abnormalities of chromosome 1 had been treated with busulfan or vercyte only. In the present study, the therapeutic records in CP were available for 97 $\mathrm{Ph}^{1}$-positive patients. Most of them were treated with busulfan, dibromomannitol, and/or vercyte, but those who received intensive therapy prior to the chromosome examination were very few. As shown in Table 6, additional chromosome changes were less frequent in the patients whose chromosomes were examined in CP only, especially before therapy. By contrast, the incidence of additional changes were much higher in the patients examined after therapy in BP. It can not be decided, however, whether these additional changes were induced by the therapy, or they have developed simply as the result of progressive karyotypic evolution that occurred in association with the malignant growth. The frequencies of cells with structural changes other than $\mathrm{i}(17 \mathrm{q})$ were almost the same as those with $+8, \mathrm{i}(17 \mathrm{q})$, $+19,+\mathrm{Ph}^{1}$, and/or other numerical changes. No positive evidence was obtained in favor of the relationship between structural changes and intensive therapy as suggested by Alimena et al. (1979), although only 10 patients were subjected to intensive chemotherapy before chromosome examinations in the present study. Similar negative results have been reported by Fleischman et al. (1981).

\section{REFERENCES}

Alimena, G., Brandt, L., Dallapiccola, B., Mitelman, F., and Nilsson, P.G. 1979. Secondary chromosome changes in chronic myeloid leukemia: Relation to treatment. Cancer Genet. Cytogenet. 1: 79-85.

Alimena, G., Dallapiccola, B., Mitelman, F., and Montuoro, A. 1980. Aberrations of chromosome no. 1 in blastic phase of chronic myeloid leukemia. Hereditas 92: 59-63.

Bernstein, R., Morcom, G., Pinto, M.R., Mendelow, B., Dukes, I., Penfold, G., and Bezwoda. 1980. Cytogenetic findings in chronic myeloid leukemia (CML); Evaluation of karyotype, blast morphology, and survival in the acute phase. Cancer Genet. Cytogenet. 2: 23-37.

Borgström, G.H. 1981. New types of unusual and complex Philadelphia chromosome $\left(\mathrm{Ph}^{1}\right)$ translocations in chronic myeloid leukemia. Cancer Genet. Cytogenet. 3: 19-31.

Brodeur, G.M., Dow, L.W., and Williams, D.L. 1979. Cytogenetic features of juvenile chronic myelogenous leukemia. Blood 53: 812-819.

Canellos, G.P., Whang-Peng, J., and DeVita, V.T. 1976. Chronic granulocytic leukemia without the Philadelphia chromosome. Am. J. Clin. Pathol. 65: 467-470.

Chessells, J.M., Janossy, G., Lawler, S.D., and Secker Walker, L.M. 1979. The Ph ${ }^{1}$ chromosome in childhood leukaemia. Brit. J. Haematol. 41: 25-41.

Engle, E., McGee, B.J., Myers, B.J., and Krantz, S.B. 1977. Chromosome banding patterns of 49 cases of chronic myelocytic leukemia. New Engl. J. Med. 296: 1295. 
Ezdinli, E.Z., Sokal, J.E., Crosswhite, L., and Sandberg, A.A. 1970. Philadelphia-chromosomepositive and -negative chronic myelocytic leukemia. Ann. Intern. Med. 72: 175-182.

FIWCL: First International Workshop on Chromosomes in Leukemia. 1978. Chromosomes in $\mathrm{Ph}^{1}$-positive chronic granulocytic leukemia. Brit. J. Haematol. 39: 305-309.

Fleischman, E.W., Prigogina, E.L., Volkova, M.A., Frenkel, M.A., Zakhartchenko, N.A., Konstantinova, L.N., Puchkova, G.P., and Balakirev, S.A. 1981. Correlations between the clinical course, characteristics of blast cells and karyotype patterns in chronic myeloid leukemia. Hum. Genet. 58 : 285-293.

Fraisse, J., Jaubert, J., Vasselon, C., and Brizard, C.P. 1980. Étude cytogénétique de 44 cas de LMC en bandes R. Nouv. Rev. Fr. Hématol. Suppl. 22: 86.

Gahrton, G., Friberg, K., Lindsten, J., and Zech, L. 1978. Duplication of part of the long arm of chromosome 1 in myelofibrosis terminating in acute myeloblastic leukemia. Hereditas 88: $1-5$.

Geraedts, J.P.M., Mol. A., Ottolander, G.J.Den, Van Der Ploeg, M., and Pearson, P.L. 1977. Variation in the chromosomes of CML patients. Helsinki Chromosome Conference 1977. Abstr. Book, p. 194.

Hagemeijer, A., Stenfert Kroeze, W.F., and Abels, J. 1980. Cytogenetic follow-up of patients with nonlymphocytic leukemia I. Philadelphia chromosome-positive chronic myeloid leukemia. Cancer Genet. Cytogenet. 2: 317-326.

Hayata, I., Sakurai, M., Kakati, S., and Sandberg, A.A. 1975. Chromosomes and causation of human cancer and leukemia XVI. Banding studies of chronic myelocytic leukemia, including five unusual $\mathrm{Ph}^{1}$ translocations. Cancer 36: 1177-1191.

Hayata, I., and Sasaki, M. 1976. A case of $\mathrm{Ph}^{1}$-positive chronic myelocytic leukemia associated with complex translocations. Proc. Jpn. Acad. 52: 29-32.

ISCN: An International System for Human Cytogenetic Nomenclature. 1978. Cytogenet. Cell Genet. 21: 309-409.

Kessous, A., Colombies, P., Sudries, M., Bourrouillou, G., Pris, J., and Clement, D. 1980. Complex $\mathrm{Ph}^{1}$ translocation in chronic myeloid leukemia. Cancer Genet. Cytogenet. 2: 335--337.

Kohno, S., and Sandberg, A.A. 1980. Chromosomes and causation of human cancer and leukemia: XXXIV. Usual and unusual findings in Ph'-positive CML. Cancer 46: 2227-2237.

Kolitz, J.E., Schulman, P., Kardon, N., Budman, D.R., Vinciguerra, V.P., Broekman, A., and Degnan, T.J. 1981. A complex variant Philadelphia $\left(\mathrm{Ph}^{1}\right)$ chromosome translocation involving chromosomes No. 11, 14, and 22 in a case of chronic myelogenous leukemia. Cancer Genet. Cytogenet. 4: 185-188.

Lawler, S.D., O'Malley, F., and Lubb, D.S. 1976. Chromosome banding studies in Philadelphia chromosome positive myeloid leukemia. Scand. J. Haematol. 17: 17-28.

Lawler, S.D. 1977. The cytogenetics of chronic granulocytic leukemia. Clin. Haematol. 6: 55-75.

Mitelman, F., and Levan, G. 1981. Clustering of aberrations to specific chromosomes in human neoplasms. IV. A survey of 1,871 cases. Hereditas 95: 79-139.

Miyamoto, K., Hamasaki, K., Kitajima, K., Adachi, T., Tanaka, T., and Sato, J. 1981. Abnormalities of chromosome No. 1 related to blood dyscrasias: Study of 10 cases. Acta Med. Okayama 35: 137-141.

Oshimura, M., Ohyashiki, K., Terada, H., Takaku, F., and Tonomura, A. 1982. Variant $\mathrm{Ph}^{1}$ translocations in CML and their incidence, including two cases with sequential lymphoid and myeloid crises. Cancer Genet. Cytogenet. 5: 187-201.

Pasquali, F., Casalone, R., Francesconi, D., Peretti, D., Fraccaro, M., Bernasconi, C., and Lazzarino, M. 1979. Transposition of $9 q 34$ and 22 (q11 $\rightarrow$ qter) regions has a specific role in chronic myelocytic leukemia. Hum. Genet. 52: 55-67.

Potter, A.M., Sharp, J.C., Brown, M.J., and Sokol, R.J. 1975. Structural rearrangements associated with the $\mathrm{Ph}^{1}$ chromosome in chronic granulocytic leukemia. Hum. Genet. 29: 223-228. 
Potter, A.M., Watmore, A.E., Cooke, P., Lilleyman, J.S., and Sokol, R.J. 1981. Significance of non-standard Philadelphia chromosomes in chronic granulocytic leukemia. Brit. J. Cancer 44: 51-54.

Prigogina, E.L., Fleischman, E.W., Volkova, M.A., and Frenkel, M.A. 1978. Chromosome abnormalities and clinical and morphologic manifestations of chronic myeloid leukemia. Hum. Genet. 41: 143-156.

Rowley, J.D. 1973. A new consistent chromosomal abnormality in chronic myelogenous leukemia identified by quinacrine fluorescence and Giemsa staining. Nature 243: 290-293.

Rowley, J.D., Wolman, S.R., and Horland, A.A. 1976. Another variant translocation in chronic myelogenous leukemia-revisited. New Engl. J. Med. 295: 900-901.

Rowley, J.D. 1978. Abnormalities of chromosome No. 1: Significance in malignant transformation. Virchows Arch. B Cell Pathol. 29: 139-144.

Rowley, J.D. 1980. $\mathrm{Ph}^{1}$-positive leukemia, including chronic myelogenous leukemia. Clin. Haematol. 9: 55-86.

Sadamori, N., Matsunaga, M., Yao, E., Nishino, K., Tomonaga, Y., Tagawa, M., Kusano, M., and Ichimaru, M. 1980. Chromosomes in the chronic phase of chronic granulocytic leukemia. Cancer Genet. Cytogenet. 1: 299-310.

Sandberg, A.A. 1978. Chromosomes in the chronic phase of CML. Virchows Arch. B Cell Pathol. 29: 51-55.

Sandberg, A.A. 1980. The cytogenetics of chronic myelocytic leukemia (CML): Chronic phase and blastic crisis. Cancer Genet. Cytogenet. 1: 217-228.

Seabright, M., and Pearson, J. 1978. Cytogenetic findings in 108 cases of chronic myeloid leukemia. Clin. Genet. 14: 308-309.

Sonta, S., and Sandberg, A.A. 1977. Chromosomes and causation of human cancer and leukemia. XXI. Unusual and complex $\mathrm{Ph}^{1}$ translocations and their clinical significance. Blood 50: 691697.

Sonta, S., and Sandberg, A.A. 1978. Chromosomes and causation of human cancer and leukemia. XXIX. Further studies on karyotypic progression in CML. Cancer 41: 153-163.

Shabtai, F., Gafter, U., Weiss, S., Djaldetti, M., and Halbrecht, I. 1980. New complex $\mathbf{P h}^{1}$ translocation $\mathrm{t}(10 ; 14 ; 22)$ in bone marrow cells and PHA-stimulated peripheral blood cultures in chronic myelocytic leukemia. J. Cancer Res. Clin. Oncol. 96: 287-294.

Slavutsky, I., Labal de Vinuesa, M., Dupont, J., Mondini, N., and Brieux de Salum, S. 1981. Abnormalities of chromosome No. 1: Two cases with lymphocytic lymphomas. Cancer Genet. Cytogenet. 3: 341-346.

Stoll, C., and Oberling, F. 1979. Non-random clonal evolution in 45 cases of chronic myeloid leukemia. Leukemia Res. 3: 61-66.

Sudries, M., Kessous, A., Bouroullou, G., Colombies, P., and Clement, D. 1980. Frequence des translocations inhabituelles du chromosome $\mathrm{Ph}^{1}$ impliquant trois chromosomes dans und étude de 68 cas de leucémie myeloide chronique. Nouv. Rev. Fr. Hématol. Suppl. 22; 89.

Tomiyasu, T., Sasaki, M., and Abe, S. 1980. Long arm deletion of chromosome No. 5 in a case of Philadelphia chromosome-positive chronic myelocytic leukemia. Cancer Genet. Cytogenet. 2: 309-315. 